Food Additives \& Contaminants

\title{
Pesticide residues and estrogenic activity in fruit and vegetables sampled from major fresh produce markets in South Africa
}

MT Mutengwe' ${ }^{1}$ NH Aneck-Hahn², L Korsten ${ }^{*}$, MC van Zij1², and C de Jager ${ }^{2}$

1. Department of Plant Science, Institute for Food Nutrition and Well-Being, University of Pretoria, Private Bag X20, Hatfield, 0028, South Africa.

2. Environmental Chemical Pollution and Health Research Unit, Faculty of Health Sciences, University of Pretoria.

\begin{abstract}
*Correspondence author. Mailing address: Department of Plant Sciences, Institute for Food Nutrition and Well-Being, University of Pretoria, South Africa. Phone: +27 12420 3295. Fax: +27 124204588. Electronic mail address: lise.korsten@up.ac.za.
\end{abstract}

\begin{abstract}
Food is likely to be one of the major pathways through which people are exposed to endocrine disrupting chemicals. With the exception of residual effects, there are concerns that a number of naturally occurring and synthetic chemicals exert adverse effects upon endocrine systems in wild life and humans. The current study reported on selected pesticide concentrations and the total estrogenic activity of fruit and vegetables using the recombinant Yeast Estrogen Screen (YES) and T47D-KBluc reporter gene assays. A total of 53 food samples (27 fruit and 26 vegetables) from Joburg and Tshwane Fresh Produce Markets (in South Africa) were analysed. Of these 17 contained one to three different pesticide residues with a concentration ranging between 0.01 and $0.68 \mathrm{mg} / \mathrm{kg}$, where-as in the rest of the samples no residues were detected. All pesticides detected except in one sample were below the maximum residue level (MRL), but others were unauthorised for use in specified fruit and vegetables. Estrogenic activity was detected in $26.4 \%$ (14 samples) of the samples tested, and the estradiol equivalents ranged from 0.007 to $2 \mathrm{pg} / \mathrm{g}$. Although the estrogenic activity was low, it may contribute to adverse health effects. Continuous monitoring for pesticides in fruit and vegetables is important, in view of the unauthorised pesticides detected in produce from South Africa and the endocrine
\end{abstract}


disrupting chemical activity found.

Keywords: Fresh produce, agricultural chemicals, estrogenic activity, endocrine disrupting chemicals, yeast estrogen screen, T47D-KBluc.

\section{Introduction}

Naturally occurring and synthetic chemicals are suspected to possess endocrine disrupting properties, which provide a potential threat to human and wildlife reproduction (Bergman et al. 2013). An endocrine disrupting chemical (EDC) is defined as an exogenous substance or mixture that alters function(s) of the endocrine system and consequently causes adverse health effects in an organism, or its progeny, or (sub) populations (World Health Organization 2002). A wide range of chemicals is thought to cause endocrine disruption. Endocrine disrupting chemicals are found in many everyday products including metal food cans, plastic bottles, toys, cosmetics, pesticides and detergents (National Institute of Environmental Health Sciences 2006). Metzler et al. (1998) state that EDCs are of diverse chemical structures and vary in potency. Endocrine disrupting chemicals include natural (e.g. phytoestrogens) and synthetic chemicals used as industrial solvents/lubricants and their by-products (e.g. polychlorinated biphenyls, polybrominated biphenyls, dioxins), pesticides (e.g. methoxychlor, chlorpyrifos, dichlorodiphenyltrichloroethane (DDT)), plasticisers (e.g. phthalates), fungicides (e.g. vinclozolin) and pharmaceutical agents (e.g. diethylstilbestrol) (Diamanti-Kandarakis et al. 2009). Some pesticides with endocrine disruptive properties include biocides, fungicides, herbicides, and insecticides, which are commonly used in agriculture.

Estrogenic activity has also been reported from naturally occurring and environmental contaminants. Phytoestrogens are natural ingredients of certain food such as soybeans, apples, cherries, wheat, and peas (Moon et al. 2006). Phytoestrogens possess oestrogenic effects in vitro and in vivo and have been responsible for reproductive disorders in some animals (Santti et al. 1998). Some heavy metals such as cadmium, mercury, arsenic, lead, manganese and zinc are suspected to affect the endocrine system, producing alterations in physiological functions (Iavicoli et al. 2009). 
Exposure to metals may results in risk of diabetes (Kuo et al. 2013), obesity (Thayer et al. 2012), synergistic effects and cardiovascular disease (Zeliger 2013). Metals have also been implicated in influencing estrogen receptor-mediated signalling and may disrupt the glucocorticoid receptor, which regulates a wide range of biological processes in humans, including insulin sensitivity (Bergman et al. 2013).

Exposure to EDCs may cause disorders of the endocrine system in a number of ways (Mendes 2002); through ingestion of contaminated food and water, and inhalation (of pesticide fumes) or via dermal absorption (World Health Organization 2003). The ingestion of food containing added antioxidants, compounds migrating from wrapping materials and pesticide residues found on or in fruit, vegetables, beef and dairy products, is assumed to be the major route of human exposure to EDCs (Ganna \& Sato 2005). All systems in the body are linked, controlled and coordinated by hormones and can be disturbed by hormone disruptors (Ying et al. 2004). There are several ways in which endocrine disrupting pesticides can interfere with the endocrine system: they can mimic, block or inhibit the action of natural occurring hormones (Sonnenschein \& Soto 1998). Mehrpouret et al. (2014) reported that pesticides may act as endocrine disrupting chemicals through hormonal or gonadotrophic pathways that affect male reproduction. For example, parathion and methyl parathion, which structurally mimic estrogen, interact with hormone receptors and interfere with gene transcription. Endocrine disrupting chemicals have been linked to a wide range of human health problems such as an increase in birth defects, an increase in sexual abnormalities, an increase in reproductive failure, and an increase in neuro developmental disorders and risk of cancers (Bergman et al. 2013).

Several studies have reported that several pesticides are recognised for their endocrine disrupting impact. For example, endosulfan had estrogenic activity (Soto et al. 1994; Andersen et al. 2002; Bonefeld-Jorgensen 2005) and can enter into the body through different routes causing cancer, oxidative stress, neurotoxic effects, and damage to adrenal glands (Bergman et al. 2013). Another pesticide used in the agricultural industry is chlorpyrifos. A known EDC that has been associated with obesity, diabetes and cardiovascular problems later in life (Cal Environmental Protection Agency 2010). Many endocrine-related diseases and disorders are on the rise. There is limited 
research on identifying and assessing estrogenic activity associated with consumption of fresh fruit and vegetables. The aim of this study was to identify and assess estrogenic activity in fruit and vegetable samples obtained from the major fresh produce markets in South Africa using the recombinant Yeast Estrogen Screen (YES) and the T47D-KBluc receptor gene assay.

\section{Materials and methods}

Materials used for pesticide residues analysis

The magnesium sulphate (MgSO4) and sodium ( $\mathrm{Na} 2)$ hydrogencitrate sesquihydrate were purchased from Sigma-Adrichin Johannesburg, South Africa. Sodium chloride (NACI) was purchased from Associated Chemical Enterprises (Pty) Ltd in Johannesburg. Trisodium $\left(\mathrm{Na}_{3}\right)$ citrate dehydrate was purchased from Merck (Pty) Ltd in Modderfontein, in South Africa. The primary secondary amine (PSA) to remove acids (including fatty acids), sugars and some pigments was purchased from Chemetrix Pty Ltd (Agilent Technologies) in Johannesburg. The solvents acetonitrile, Chlomason ${ }^{\circledR}$ gradient grade and HPLC grade ethanol were purchased from SigmaAdrich. Acetone and hexane distilled were purchased from Associated Chemical Enterprises (Pty) Ltd in Johannesburg.

\section{Materials used for assessing estrogenic activity}

The yeast cells were obtained from Prof. J.P. Sumpter's laboratory, in the Department of Biology and Biochemistry, Brunel University, Uxbridge, Middlesex in the United Kingdom. T47D-KBluc cells were purchased from the American Type Culture Collection (CRL-2865TM). 17ß-estradiol ( $\left.\mathrm{E}_{2}\right)$, Roswell Park Memorial Institute-1640 (RPMI-1640) powder, sodium bicarbonate $\left(\mathrm{NaHCO}_{3}\right)$, glycylglycine, adenosine 5'triphosphate (ATP), bovine serum albumin (BSA) and magnesium chloride solution $\left(\mathrm{MgCl}_{2}\right)$ were purchased from Sigma-Aldrich, ICI 182,780 was from Tocris biosciences (Missouri, United States of America (USA)) and HPLC grade ethanol and $\mathrm{D}(+)$-glucose from Merck. Chlorophenol red- $\beta$-d-galactopyranoside (CPRG) was from Roche Diagnostics (Mannheim, Germany). HEPES buffer solution, sodium 
pyruvate, antibiotic/antimycotic solution and phosphate buffered saline (PBS) were from Gibco (Life Technologies Corporation, Paisley, United Kingdom). Characterised fetal bovine serum (FBS) and charcoal/dextran treated FBS were purchased from Hyclone Laboratories (Utah, USA). Reporter lysis buffer and beetle luciferin were from Promega (Madison, USA).

\section{Collection and preparation of food samples}

Fifty-three food samples (27 fruit and 26 vegetables) were collected from the two biggest fresh produce markets in South Africa (Joburg and Tshwane fresh produce markets). Joburg Fresh Produce Market (JFPM) being the largest as it commands nearly $40 \%$ of the national market share in both volume and turnover, and trades twice the volume of fresh produce of the second biggest market, namely the Tshwane Fresh Produce Market (Joburg Market Business Plan 2015/2016). In an international context, Joburg fresh produce market is the biggest fresh produce market in Africa in terms of volume of fresh produce traded (Joburg Market Business Plan 2015/2016). The sample weight was a minimum of $1 \mathrm{~kg}$ for small- and medium-size fresh produce and $2 \mathrm{~kg}$ for large produce (Codex Alimentarius 2000). The samples were placed in plastic bags, coded and transported in cooler boxes for immediate processing. As part of the sampling procedure and for background information purposes, producers were requested to provide the spraying programmes, which included chemicals used, volume sprayed and date of application. All the samples were transported on the same day of sampling to the South African Bureau of Standards (SABS) Laboratory, Chromatographic Services in Pretoria, accredited in terms of International Standards Organization (ISO) 17025:2005(South African National Accreditation System (SANAS) Accreditation No: T0270). All samples were prepared on arrival and stored in a freezer $\left(-18^{\circ} \mathrm{C}\right)$. For the analysis, only the edible portion was included. Bruised and rotten part was removed.

\section{Extraction procedure for fruit and vegetables samples}

The first extraction of raw fruit and vegetable samples was conducted according to the SABS in-house test method 029/2006 with reference to the Quick, Easy, Cheap, 
Effective, Rugged, and Safe (QuEChERS) mini-multiresidue method for the determination of pesticide residues in low-fat products (Anastassiades et al. 2003). After the first extraction, the acetonitrile layer containing the pesticides was purified from the contaminating matrix. For further purification, an aliquot was removed in order to undergo a second extraction by dispersive solid phase extraction (dSPE) containing both $\mathrm{MgSO}_{4}$ for further water absorption and primary secondary amine (PSA) to remove acids (including fatty acids), sugars and some pigments. An aliquot of acetonitrile layer was removed and added to the appropriate dSPE tube, which contained $150 \mathrm{mg} \mathrm{MgSO}_{4}$, and $25 \mathrm{mg}$ PSA. Graphitised carbon black (GCB) was added to samples with high amounts of chlorophyll or carotinoids. After the addition of $2.5 \mathrm{mg} \mathrm{GCB}$, the $2 \mathrm{~mL}$ dSPE tubes were all capped and shaken for 30 seconds to two minutes and then centrifuged for one minute at $>3000 \mathrm{~g}$. The aliquot was transferred into screw cap vials, and acidified using $10 \mu \mathrm{L} \mathrm{5 \%} \mathrm{(v/v)} \mathrm{and} \mathrm{formic} \mathrm{acid} \mathrm{in}$ acetonitrile $(10 \mu \mathrm{L} / \mathrm{ml}$ extract $)$ adjust the $\mathrm{pH}$ to 5.0-5.5.

\section{Pesticide residue analysis}

The fruit and vegetable extracts were transferred to auto-sampler vials and analysed for pesticide residue using gas chromatography (GC) and mass spectrometry (MS) techniques (Anastassiades et al. 2003). The limit for quantification of pesticides was $0.01 \mathrm{ppm}$ (Anastassiades et al. 2003). The scope of pesticide residues are depicted in Table 1.

\section{Bio-assay analysis}

The fruit and vegetable extracts were transferred into screw cap vials and transported in a cooler box from the SABS Laboratory to the EDC Laboratory at the Environmental Chemical Pollution and Health Research Unit, University of Pretoria, for estrogenic activity assessment. Extracts were kept at $-20^{\circ} \mathrm{C}$. The YES screen and T47D-KBluc Reporter gene assay were used in this study to assess estrogenic activity of the fruit and vegetable extracts. Preparation of media, general cell maintenance and assay procedures were carried out according to the protocols described in the Water Research Council (WRC) EDC Toolbox (De Jager et al. 2011). 
Table 1. List of pesticides within the scope of analysis (by the SABS in-house method 029/2006)

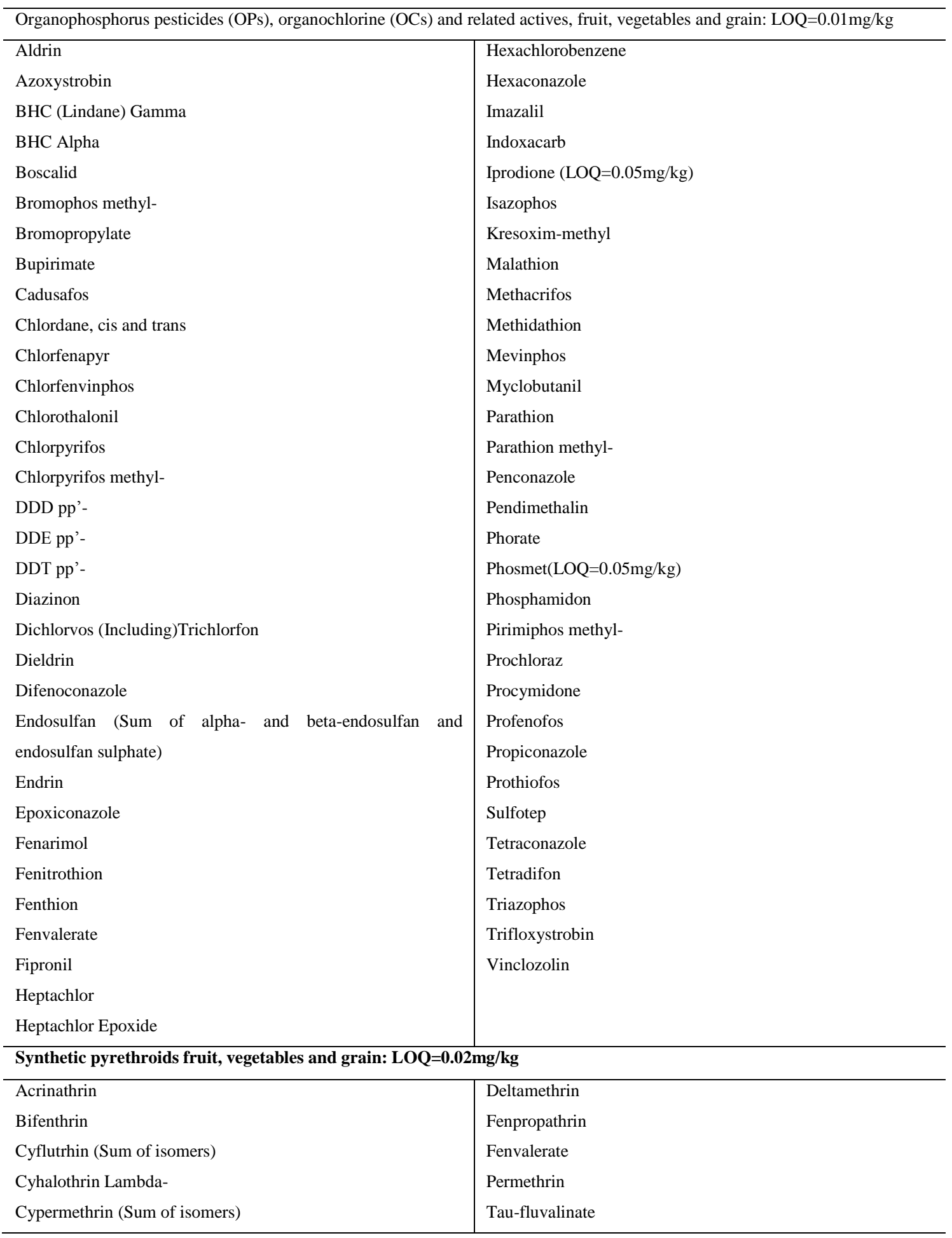

\section{YES assay}

The YES assay was developed at the Genetics Department at Glaxo. Yeast cells were transfected with the estrogen receptor alpha $(\mathrm{ER} \alpha)$ gene, together with expression 
plasmids, containing estrogen-responsive elements and the lac- $Z$ reporter gene encoding the enzyme $\beta$-galactosidase. Compounds that bind to and activate the ER will result in the production of $\beta$-galactosidase. This enzyme causes the chromogenic substrate, chlorophenol red- $\beta$-d-galactopyranoside (CPRG) present in the assay medium, to change from yellow into a red product that can be measured by absorbance (Routledge \& Sumpter 1996). To determine the estrogenic activity of the fruit and vegetable extracts, serial dilutions of the extracts and controls $\left(\mathrm{E}_{2}\right.$ positive control and ethanol solvent control) were made in ethanol and $10 \mu \mathrm{L}$ aliquots were transferred to triplicate 96 well micro-titre plates and allowed to evaporate to dryness. Assay medium containing the yeast and chromogenic substrate, CPRG, were then dispensed into each sample well $(200 \mu \mathrm{L}$ per well) and the plates were incubated at $32^{\circ} \mathrm{C}$ for 3 up to 5 days (Heraeus, B290 naturally ventilated incubator). On day 3 to 5 the absorbance was measured at $540 \mathrm{~nm}$ for colour change and $620 \mathrm{~nm}$ for turbidity of the yeast culture using a Multiskan Spectrum 96-well plate reader (Thermo Fisher Scientific). The following equation was applied to correct for turbidity:

Corrected value $=$ test absorbance $(540 \mathrm{~nm})-[$ test absorbance $(620 \mathrm{~nm})-$ median blank absorbance $(620 \mathrm{~nm})]$

The detection limit of the yeast assay was calculated as absorbance elicited by the solvent control (blank) plus three times the standard deviation. The estradiol equivalents (EEqs) were calculated for samples with three or more points above the detection limit.

\section{T47D-KBluc reporter gene assay}

The T47D-KBluc cell line was developed by Wilson et al. (2004), to screen chemicals for estrogenic and anti-estrogenic activity. T47D human breast cancer cells naturally express ER $\alpha$ and ER $\beta$ and were transfected with an estrogen-responsive element (ERE) luciferase reporter gene construct. Luciferase is produced when estrogenic compounds bind to and activate the ER and can be quantified by measuring the light produced when the enzyme substrate, luciferin, and appropriate cofactors are added. T47D-KBluc cells were maintained in RPMI-1640 growth media supplemented with 
$2.5 \mathrm{~g} / \ell$ glucose, $10 \mathrm{mM}$ HEPES, $1 \mathrm{mM}$ sodium pyruvate, $1.5 \mathrm{~g} / \ell \mathrm{NaHCO}_{3}, 10 \% \mathrm{FBS}$, $100 \mu \mathrm{g} / \mathrm{m} \ell$ penicillin, $100 \mathrm{U} / \mathrm{m} \ell$ streptomycin and $0.25 \mu \mathrm{g} / \mathrm{m} \ell$ amphotericin B. One week prior to the assay, cells were placed in growth media modified by replacement of 10\% FBS with 10\% dextran-charcoal-treated FBS and excluding antibiotic supplements. Dosing dilutions were prepared in growth media containing 5\% dextrancharcoal treated FBS. Cells were seeded at $5 \times 10^{4}$ cells per well in 96-well luminometer plates and were exposed to sample extracts and controls. Each sample was tested alone as well as in the presence of the $E_{2}$ agonist control to test for antiestrogenic activity. An agonist positive control $\left(\mathrm{E}_{2}\right)$, negative control (vehicle only), antagonist control ( $E_{2}$ plus ICI) and background control (vehicle plus ICI) were included on each plate. The final volume in each well was $100 \mu \mathrm{L}$ and the vehicle control (ethanol) did not exceed $0.2 \%$. The plates were incubated for $24 \mathrm{~h}$ at $37^{\circ} \mathrm{C}, 5 \%$ $\mathrm{CO}_{2}$. The cells were washed with phosphate buffered saline, $25 \mu \mathrm{L}$ lysis buffer was added per well and the lysis buffer was activated by one freeze-thaw cycle. Luciferase activity was determined using a LUMIstar OPTIMA luminometer (BMG Labtech) and quantified as relative light units. Each well received $25 \mu \mathrm{L}$ reaction buffer $(25$ $\mathrm{mM}$ glycylglycine, $15 \mathrm{mM} \mathrm{MgCl}_{2}, 5 \mathrm{mM}$ ATP, $0.1 \mathrm{mg} / \mathrm{mL}$ BSA, $\mathrm{pH}$ 7.8), followed by $25 \mu \mathrm{L} 1 \mathrm{mM}$ D-luciferin 5 s later. Relative light units were converted to a fold induction above the vehicle control value and EEq values were calculated for samples with greater than a two-fold induction above the vehicle control.

\section{Estradiol equivalents calculation}

The $E_{2}$ standard curve was fitted (sigmoidal function, variable slope) using Graphpad Prism (version 4), which calculated the minimum, maximum, slope, $\mathrm{EC}_{50}$ value and 95\% confidence limits. Estradiol equivalent of fruit and vegetable extracts were interpolated from the estradiol standard curve and corrected with the appropriate dilution factor for each sample. Estradiol equivalent values were reported as the average \pm the standard deviation (SD) of three independent repeats.

\section{Results}

\section{Pesticide concentrations in fruit and vegetables}

Of the 53 samples analysed, 36 did not contain any pesticide residues. The remaining 
Table 2. Pesticide concentrations and estrogenic activity of fruit and vegetables

\begin{tabular}{|c|c|c|c|c|c|c|}
\hline \multirow{2}{*}{$\begin{array}{l}\text { Fruit / } \\
\text { Vegetable }\end{array}$} & \multirow[t]{2}{*}{ Pesticide residues } & \multirow{2}{*}{$\begin{array}{l}\text { MRL } \\
\text { Set }\end{array}$} & \multirow{2}{*}{$\begin{array}{l}\text { Complying } \\
\text { with } \\
\text { MRLs }\end{array}$} & \multirow{2}{*}{$\begin{array}{l}\text { YES assay } \\
\text { Estrogenic } \\
\text { Activity } \\
\text { (EEqpg/g) }\end{array}$} & \multicolumn{2}{|l|}{ KBluc assay } \\
\hline & & & & & $\begin{array}{l}\text { Estrogenic } \\
\text { activity } \\
\text { (EEqpg/g) }\end{array}$ & $\begin{array}{l}\text { Anti-estrogenic activity } \\
\text { (ICI EEqpg/g) }\end{array}$ \\
\hline Apples & LOQ & & Yes & $<\mathrm{dl}$ & $0.2 \pm 0.07$ & $<\mathrm{dl}$ \\
\hline Apples & LOQ & & Yes & $<\mathrm{dl}$ & $0.3 \pm 0.2$ & $<\mathrm{dl}$ \\
\hline Apples & LOQ & & Yes & $<\mathrm{dl}$ & $<\mathrm{dl}^{*}$ & $<\mathrm{dl}$ \\
\hline Apples & Iprodione $0.44(\mathrm{R})$ & 2.5 & Yes & $<\mathrm{dl}$ & $<\mathrm{dl}$ & $<\mathrm{dl}$ \\
\hline Cabbage & LOQ & & Yes & $<\mathrm{dl}$ & $<\mathrm{dl}^{*}$ & $<\mathrm{dl}$ \\
\hline Cabbage & LOQ & & Yes & $<\mathrm{dl}$ & $<\mathrm{dl}$ & $<\mathrm{dl}$ \\
\hline Cabbage & LOQ & & Yes & $<\mathrm{dl}$ & $1.6 \pm 0.04$ & $<\mathrm{dl}$ \\
\hline Cabbage & LOQ & & Yes & $<$ loq & $2 \pm 0.3$ & $<\mathrm{dl}$ \\
\hline Cabbage & Chlorpyrifos $0.03(\mathrm{R})$ & 0.1 & Yes & $<\mathrm{dl}$ & $<\mathrm{dl}$ & $<\mathrm{dl}$ \\
\hline Cabbage & Chlorpyrifos $0.01(\mathrm{R})$ & 0.1 & Yes & $<\mathrm{dl}$ & $<\mathrm{dl}$ & $<\mathrm{dl}$ \\
\hline Carrots & LOQ & & Yes & $<\mathrm{dl}$ & $<\mathrm{dl}$ & $<\mathrm{dl}$ \\
\hline Carrots & LOQ & & Yes & $<$ loq & $<\mathrm{dl}$ & $<\mathrm{dl}$ \\
\hline Carrots & Chlorpyrifos 0.05 (R) & 0.05 & Yes & $<\operatorname{loq}$ & $<\mathrm{dl}$ & $<\mathrm{dl}$ \\
\hline \multirow[t]{3}{*}{ Carrots } & Boscalid 0.02 (UR) & & No & $<\mathrm{dl}$ & $<\mathrm{dl}$ & $<\mathrm{dl}$ \\
\hline & Chlorpyrifos 0.02 (R) & 0.05 & Yes & $<\mathrm{dl}$ & $<\mathrm{dl}$ & $<\mathrm{dl}$ \\
\hline & Procymidone 0.02 (UR) & & No & $<\mathrm{dl}$ & $<\mathrm{dl}$ & $<\mathrm{dl}$ \\
\hline \multirow[t]{2}{*}{ Carrots } & Difenoconazole $0.01(\mathrm{R})$ & 0.01 & Yes & $<\mathrm{dl}$ & $<\mathrm{dl}$ & $<\mathrm{dl}$ \\
\hline & Procymidone 0.05 (UR) & & No & $<\mathrm{dl}$ & $<\mathrm{dl}$ & $<\mathrm{dl}$ \\
\hline Lettuce & LOQ & & Yes & $<\mathrm{dl}$ & $<\mathrm{dl}$ & $<\mathrm{dl}$ \\
\hline Lettuce & LOQ & & Yes & $<\operatorname{loq}$ & $<\mathrm{dl}$ & $<\mathrm{dl}$ \\
\hline Lettuce & LOQ & & Yes & $<\mathrm{dl}$ & $<\mathrm{dl}$ & $<\mathrm{dl}$ \\
\hline Lettuce & LOQ & & Yes & $<\mathrm{dl}$ & $0.08 \pm 0.007$ & $<\mathrm{dl}$ \\
\hline Lettuce & LOQ & & Yes & $<\mathrm{dl}$ & $1.3 \pm 0.03$ & $<\mathrm{dl}$ \\
\hline Peaches & LOQ & & Yes & $<$ loq & $<\mathrm{dl}$ & $<\mathrm{dl}$ \\
\hline Peaches & LOQ & & Yes & $<\operatorname{loq}$ & $<\mathrm{dl}$ & $<\mathrm{dl}$ \\
\hline Pears & LOQ & & Yes & $<\mathrm{dl}$ & $<\mathrm{dl}$ & $<\mathrm{dl}$ \\
\hline Pears & LOQ & & Yes & $<\mathrm{dl}$ & $<\mathrm{dl}$ & $<\mathrm{dl}$ \\
\hline Pears & LOQ & & Yes & $<\mathrm{dl}$ & $<\mathrm{dl}$ & $<\mathrm{dl}$ \\
\hline Pears & LOQ & & Yes & $<\mathrm{dl}$ & $0.08 \pm 0.01$ & $<\mathrm{dl}$ \\
\hline Pears & LOQ & & Yes & $<\mathrm{dl}$ & $<\mathrm{dl}$ & $<\mathrm{dl}$ \\
\hline Pears & Azoxystrobin 0.01 (UR) & & No & $<\mathrm{dI}$ & $<\mathrm{dl}$ & $<\mathrm{dl}$ \\
\hline Plums & LOQ & & Yes & $<\mathrm{dl}$ & $<\mathrm{dl}$ & $<\mathrm{dl}$ \\
\hline Plums & LOQ & & Yes & $<\mathrm{dl}$ & $<\mathrm{dl}$ & $<\mathrm{dl}$ \\
\hline Plums & LOQ & & Yes & $<\operatorname{loq}$ & $<\mathrm{dl}$ & $<\mathrm{dl}$ \\
\hline Plums & LOQ & & Yes & $<\operatorname{loq}$ & $<\mathrm{dl}$ & $<\mathrm{dl}$ \\
\hline Plums & Iprodione $0.49(\mathrm{R})$ & 5 & Yes & $<\mathrm{dl}$ & $<\mathrm{dl}$ & $<\mathrm{dl}$ \\
\hline Spinach & LOQ & & Yes & $<$ loq & $<\mathrm{dl}$ & $3000 \mathrm{pg} / \mathrm{g}$ ICI equivalents \\
\hline Spinach & LOQ & & Yes & $<\mathrm{dl}$ & $<\mathrm{dl}$ & $<\mathrm{dl}$ \\
\hline Spinach & LOQ & & Yes & $<\mathrm{dl}$ & $<\mathrm{dl}$ & $<\mathrm{dl}$ \\
\hline Spinach & LOQ & & Yes & $<\mathrm{dl}$ & $<\mathrm{dl}$ & 900pg/g ICI equivalents \\
\hline Spinach & Endosulfan 0.01 (UR) & & No & $<\mathrm{dl}$ & $0.6 \pm 0.4$ & $<\mathrm{dl}$ \\
\hline Strawberries & LOQ & & Yes & $<\mathrm{dl}$ & $<\mathrm{dl}$ & $<\mathrm{dl}$ \\
\hline Strawberries & Boscalid 0.18 (UR) & & No & $<\mathrm{dl}$ & $<\mathrm{dl}^{*}$ & $<\mathrm{dl}$ \\
\hline Strawberries & Profenofos 0.01 (UR) & & No & $<$ loq & $0.2 \pm 0.1$ & $<\mathrm{dl}$ \\
\hline Table Grapes & LOQ & & Yes & $<\mathrm{dl}$ & $<\mathrm{dl}$ & $<\mathrm{dl}$ \\
\hline Table Grapes & LOQ & & Yes & $<\mathrm{dl}$ & $<\mathrm{dl}$ & $<\mathrm{dl}$ \\
\hline Table Grapes & Iprodione $0.10(\mathrm{R})$ & 5 & Yes & $<\mathrm{dl}$ & $<\mathrm{dl}$ & $<\mathrm{dl}$ \\
\hline Table Grapes & Iprodione $0.68(\mathrm{R})$ & 5 & Yes & $<\mathrm{dl}$ & $0.1 \pm 0.03$ & $<\mathrm{dl}$ \\
\hline Table Grapes & Azoxystrobin $0.12(\mathrm{R})$ & 1 & Yes & $<\mathrm{dl}$ & $<\mathrm{dl}$ & $<\mathrm{dl}$ \\
\hline \multirow[t]{2}{*}{ Table Grapes } & Azoxystrobin $0.19(\mathrm{R})$ & 1 & Yes & $<\mathrm{dl}$ & $<\mathrm{dl}$ & $<\mathrm{dl}$ \\
\hline & Iprodione $0.38(\mathrm{R})$ & 5 & Yes & $<\mathrm{dl}$ & $<\mathrm{dl}$ & $<\mathrm{dl}$ \\
\hline Table Grapes & Azoxystrobin $0.14(\mathrm{R})$ & 1 & Yes & $<\mathrm{dl}$ & $<\mathrm{dl}$ & $<\mathrm{dl}$ \\
\hline Tomatoes & LOQ & & Yes & $<\mathrm{dl}$ & $<\mathrm{dl}$ & $<\mathrm{dl}$ \\
\hline Tomatoes & LOQ & & Yes & $<$ loq & $1+0.1$ & $<\mathrm{dl}$ \\
\hline Tomatoes & LOQ & & Yes & $<\mathrm{dl}$ & $0.2 \pm 0.01$ & $<\mathrm{dl}$ \\
\hline Tomatoes & LOQ & & Yes & $<\mathrm{dl}$ & $0.2 \pm 0.02$ & $<\mathrm{dl}$ \\
\hline Tomatoes & Boscalid $0.05(\mathrm{R})$ & 0.01 & No & $<\mathrm{dl}$ & $0.3 \pm 0.08$ & $<\mathrm{dl}$ \\
\hline
\end{tabular}

EEq: estradiol equivalents

$<$ dl: below detection limit of the assay

$<$ loq: sample had points above detection limit of the assay, but activity too low to quantify

* Cytotoxicity observed when sample is concentrated

$\mathrm{R}$ : registered pesticide

UR: unregistered pesticide 
17 samples contained one to three different pesticide residues, with a concentration ranging from 0.01 to $0.68 \mathrm{mg} / \mathrm{kg}$ (Table 2). Eleven samples with detectable residues complied with maximum allowable residue levels (MRLs) according to the South African set values benchmarked to the European Union (EU) standards http://www.daff.gov.za. Tomatoes were the only sample that had a pesticide concentration exceeding the MRL, with detection of a boscalid concentration of 0.05 $\mathrm{mg} / \mathrm{kg}$ (MRL of $0.01 \mathrm{mg} / \mathrm{kg}$ ). Unregistered pesticides were detected in six samples: procymidone in carrots (2 samples), boscalid in strawberries and carrots (1 sample respectively), endosulfan in carrots (1 sample), profenofos in strawberries (1 sample) and azoxystrobin in pears (1 sample).The most frequently detected pesticide was iprodione (5 samples), azoxystrobin (4 samples), chlorpyrifos (4 samples), boscalid (3 samples), procymidone (2 samples); difenoconazole (1 sample), endosulfan and profenofos (1 sample). Carrots and table grapes were the only fresh produce found with multiple pesticide residues per sample. The highest concentration of pesticide residues was found in fruit $(0.68$ to $0.01 \mathrm{mg} / \mathrm{kg})$ and vegetables were found with the lowest concentration $(0.05$ to $0.01 \mathrm{mg} / \mathrm{kg})$.

\section{Estrogenic activity in fruits and vegetables}

Among the 53 fruit $(n=27)$ and vegetable $(n=26)$ samples analysed, estrogenic activity was detected in $26.4 \%$ (14 samples) of all samples tested. The EEq ranged from 0.007 to $2 \mathrm{pg} / \mathrm{gin}$ the T47D-KBluc bioassay. Eleven samples contained residues known to exert estrogenic activities in-vitro: procymidone in carrots (2 samples), chlorpyrifos in cabbage (2 samples) and carrots (1 sample); iprodione in table grapes (3 samples), iprodione in plums (1 sample) and apples (1 sample) and endosulfan in spinach (1 sample) (Table 3). Ten of the 53 samples analysed showed estrogenic activity but no residue was detected on the product: tomatoes ( 3 samples), apples ( 2 samples), lettuce (2 samples), cabbage (2 samples), and pears (1 sample) (Table 4). There was no correlation between the zero residue and the EEq values detected from the ten samples analysed.

Of the 53 samples tested, only four samples were detected with pesticide residues and 
Table 3. Pesticides with endocrine disrupting effects

\begin{tabular}{llll}
\hline Pesticides & Description & Endocrine effects & References \\
\hline Chlorpyrifos & Insecticide & Androgen receptor binding antagonist & Viswanath et al. 2010 \\
Endosulfan & Insecticide/ & Antagonises the action of androgens & Mnif et al. 2011; \\
& Acaricide & via binding competitively to their & Sarma \& Kalita, 2012 \\
& receptors and inhibiting the generic & \\
& & transcription they induce. Mimics the & \\
& & action of oestrogens indirectly by & \\
& & stimulating the production of their & \\
Iprodione & Fungicide & Weceptors. Weak aromatase inhibitor. & \\
& & increasing estrogens production. & Mnif et al. 2011 \\
& Competitively inhibitors the binding & Svechnikov et al. \\
& & of androgen to its receptor, inhibits & 2010; \\
& & androgen-inducing gene expression. & Tomigahara et al. \\
& & & 2014 \\
& & &
\end{tabular}

Table 4. Samples analysed showing level of EEq (pg/g) but with no pesticides detected

\begin{tabular}{lcccc}
\hline $\begin{array}{l}\text { Fruit / } \\
\text { vegetable }\end{array}$ & $\begin{array}{c}\text { Pesticide } \\
\text { residues }\end{array}$ & $\begin{array}{c}\text { Complying } \\
\text { with MRLs }\end{array}$ & $\begin{array}{c}\text { Estrogenic activity } \\
(\text { EEqpg/g) }\end{array}$ & $\begin{array}{c}\text { Anti-estrogenic } \\
\text { activity(IC EEqpg/g) }\end{array}$ \\
\hline Apples & LOQ & Yes & $0.2 \pm 0.07$ & $<\mathrm{dl}$ \\
Apples & LOQ & Yes & $0.3 \pm 0.2$ & $<\mathrm{dl}$ \\
Cabbage & LOQ & Yes & $1.6 \pm 0.04$ & $<\mathrm{dl}$ \\
Cabbage & LOQ & Yes & $2 \pm 0.3$ & $<\mathrm{dl}$ \\
Lettuce & LOQ & Yes & $0.08 \pm 0.007$ & $<\mathrm{dl}$ \\
Lettuce & LOQ & Yes & $1.3 \pm 0.03$ & $<\mathrm{dl}$ \\
Pears & LOQ & Yes & $0.08 \pm 0.01$ & $<\mathrm{dl}$ \\
Tomatoes & LOQ & Yes & $1+0.1$ & $<\mathrm{dl}$ \\
Tomatoes & LOQ & Yes & $0.2 \pm 0.01$ & $<\mathrm{dl}$ \\
Tomatoes & LOQ & Yes & $0.2 \pm 0.02$ & \\
\hline
\end{tabular}

shows level of EEq (pg/g): tomatoes (1 sample) detected with boscalid (MRL of 0.05 $\mathrm{mg} / \mathrm{kg}$ ); table grapes (1 sample) detected with iprodione (MRL of $0.68 \mathrm{mg} / \mathrm{kg}$ ), strawberries (1 sample) detected with profenofos (MRL of $0.01 \mathrm{mg} / \mathrm{kg}$ ) and spinach (1 sample) detected with endosulfan (MRL of $0.01 \mathrm{mg} / \mathrm{kg}$ ). Of the 53 samples, 3 samples were observed with cytotoxicity: strawberries (1 sample), cabbage (1 sample), and apples ( 1 sample) but the estrogenic activity was below the detection limit $(<\mathrm{dl})$ of the assay. All the samples were below the level of quantification (loq) or dl in the YES screen, as indicated in Table 2. The results obtained in the T47D-KBluc assay are shown in Table 2. Cytotoxicity, which can mask estrogenic activity, was found in 
three samples in the T47D-KBluc assay.

\section{Discussion}

This is the first study of its kind that the fruit and vegetables are sampled from the two biggest fresh produce markets in South Africa to assess for estrogenic activity. In this study the estrogenic effects of extracts from all the fruit and vegetable samples, using the recombinant YES and T47D-KBluc reporter gene assays, were investigated and reported. The quantitative evaluations of the pesticide residue results were compared to the South African set MRL values, and estrogenic activities that are associated with the pesticides identified as EDCs. Tomatoes were the only sample that had a pesticide concentration exceeding the MRL, with the detection of boscalid at a concentration of $0.05 \mathrm{mg} / \mathrm{kg}$ (MRL of $0.01 \mathrm{mg} / \mathrm{kg}$ ). Other pesticide residues detected on the various crops (carrots, pears, spinach and strawberries) are not officially permitted for use on the crop. These include azoxystrobin, boscalid, chlorfenapyr, chlorothalonil, chlorpyrifos, endosulfan, fenpropathrin, imazalil, lambda-cyhalothrin, procymidone and profenofos. Presence of unregistered pesticide residues is of concern (Bempah et al. (2011). Farag et al. (2011) study conducted in Egypt showed that some of the pesticides (malathion, carbendazim, diazinon, permethrin and quinalphos) detected as residues in the analysed food items were considered to be carcinogenic at different level of assurance. Most of the products from the farms (production unit codes) sampled were not GLOBALGAP certified. The use of unregistered or banned pesticides is an indication of deviation from good agricultural practice (GAP). The presence of residues of non-registered pesticides is alarming and strengthens the need for the government to enforce its regulations and to monitor pesticide residues on the fresh produce sold locally.

Estrogenic activity was detected in $26.4 \%$ of the samples tested in this study. Among the substances reported from the study to have ED effects were endosulfan, procymidone, chlorpyrifos, and iprodione (Mnif et al. 2011). Pesticides have different degrees of estrogenicity (Shaw \& McCully 2002). Furthermore, the fruit and vegetable extracts used in this study did not reflect the activity of any particular chemical components of foods (Charles et al. 2002). The results indicate that although 
most samples tested positive for pesticides, the level of estrogenic activity was low. A central feature of endocrine disruption is that it may cause detrimental effects on an organism at very low chemical concentrations (Fang et al. 2001; Bornman et al. 2007). Some of the effects caused by ED at very low chemical concentrations: can work together to produce additive or synergistic effects not seen with the individual chemicals and lastly EDCs can also act on a variety of physiological processes in a tissue specific manner and sometimes act via dose-response curves that are nonmonotonic (Bergman et al. 2013). The results found in this study were within the range of those found for evaluating the total estrogenic activity of fruit and vegetables in relation to pesticide residues conducted elsewhere. Schiliro et al. (2011) conducted a study in which 44 food samples, 30 fruits and 14 vegetables were evaluated for estrogenic activity in relation to pesticide residues. As in the current study, Schiliro et al. (2011) study found a low correlation between the concentration of pesticide residues and the EEq values (Spearman correlation $r=0.376$ and $\mathrm{p}=0.012$ ).

In the current study endosulfan was found only on spinach. Endosulfan is not registered for use on spinach in South Africa. Endosulfan is a toxic broad-spectrum organochlorine insecticide and acaricide used throughout the world for pest control on a variety of crops (Verma et al. 2011). Endosulfan is a proven ED (United States Environmental Protection Agency 2002) and exhibits estrogenic properties, comparable to those of Dichlorodiphenyltrichloroethane (DDT). Endosulfan competes with estradiol for binding to estrogen receptors, thereby inhibiting hormonal function (Grumfeld \& Bonefeld-Jorgensen 2004). Endosulfan has been banned for use in agricultural crops by the Stockholm Convention since April 2011 and South Africa is a member of the convention (Persistent Organic Pollutants Review Committee 2010). To prevent the usage of banned chemicals stricter rules such as paying a fine for the violation of using banned substances or being suspended from participating in local sale or exporting fresh produce for certain period needs to be introduced.

In this study chlorpyrifos residue was found in cabbage and carrots. Chlorpyrifos is a registered pesticides in South Africa for use in cabbage $(0.10 \mathrm{mg} / \mathrm{kg})$ and carrots $(0.05$ $\mathrm{mg} / \mathrm{kg}$ ). Chlorpyrifos is an organophosphate insecticide and used on a wide range of crops, in numerous non-agricultural situations and is considered to be an ED (United 
States Environmental Protection Agency 2011). Exposure to chlorpyrifos has been reported to contain estrogenic activity, which results in effects such as brain and genital defects (Eaton et al. 2008). Iprodione was found in apples, plums and table grapes. Iprodione is a registered pesticide in South Africa for use in apples (2.5 $\mathrm{mg} / \mathrm{kg}$ ), plums (5 mg/kg) and table grapes (5 mg/kg). Iprodione, a chloranaline pesticide has been shown to have anti-androgenic effects (Gray et al. 1999) and aromatase inhibition properties (Andersen et al. 2002). Procymidone was found on carrots in this study. Procymidone is however not registered for use on carrots in South Africa. The pesticide procymidone is a well-known fungicide and was shown to be present in fruit products prepared for human consumption (Ostby et al. 1999). It is a typical anti-androgen, competitively inhibiting the binding of androgens to the human androgen receptor and thereby preventing androgen-induced gene expression (Ostby et al. 1999).

Many sources of EDCs are not known because of chemical constituent declarations in products, materials and goods. The study found that 10 samples analysed showed estrogenic activity but with no pesticides detected. It is known that ED is found throughout the environment and is grouped into two major groups (Keith 1998); natural compounds such as phytoestrogens, bioflavanoids and mycoestrogens that are naturally found in the environment (Cederroth et al. 2012) and synthetic compounds that are designed for several uses such as pesticides, herbicides, and plastics that are suspected of causing disrupting endocrine system of human and wildlife (Bergman et al. 2013).

Heavy metals are present in our environment as they formed during the earth's birth (Järup 2003). Some metals have been identified as endocrine disruptors (Iavicoli et al. 2009). Metals have also been implicated in influencing estrogen receptor-mediated signalling (Watson \& Jager 2007). Toxic metals (arsenic, cadmium, lead, mercury) are ubiquitous environmental contaminants that can cause a wide range of adverse health effects in humans (Järup, 2003). Several factors may influence contaminant accumulation such as level and duration of contaminant exposure, topography, agricultural field conditions and potential bioaccumulation (Ziarati et al. 2013). In agricultural crops the main source of heavy contamination are irrigation with 
contaminated water, metal based pesticides, industrial emissions, fertilizers and transportation, harvesting process, storage and sale of crops (Duran et al. 2007). Endocrine disrupting chemicals might act synergistically or in an additive manner e.g. phytoestrogens, some heavy metals, industrial contaminants and pesticides (Kilian et al. 2007). However, further investigation may be necessary to understand the apparent discrepancy of shown levels of EEq (pg/g) and no pesticides detected. Only selected pesticides were tested, but there might be other EDCs presented, not tested for estrogenic activity.

Currently, South Africa has more than 500 registered pesticides for use on agricultural products (Pesticide Action Network 2010) and reported to be the largest fresh

produce-exporting country in sub-Saharan Africa (Ansara-Ross et al. 2012; Dabrowski et al. 2014). With the high productivity of agricultural crops and demand for quality yield, South Africa also has the highest usage of pesticide active ingredients in southern Africa (Dabrowski et al. 2014). However, only a small fraction of these chemicals have been investigated in tests capable of identifying overt endocrine effects in intact organisms. The vast majority of chemicals in current commercial use have not been tested at all. The results from this study indicate the need for expanding the assessment to other crops and pesticide classes, and to assess the estrogenic activity.

\section{Conclusion}

Fruit and vegetables in the current study contained estrogenic activity and specific individual chemical compounds known to be EDCs. The results of the study indicate that estrogenic activity was present in a significant proportion (26.4\%) of samples assessed. However, the level of estrogenic activity detected in fruit and vegetables was considered low. However, endocrine disruptors can act at very low doses and causes adverse effects on animals and humans in the range of environmental exposure, therefore this information should be considered of importance in terms of potential impact on public health. Many pesticides are in use today and new ones are being developed, there is still a major lack of data for EDCs from large parts of the world, including South Africa. Many sources of EDCs are not known because of a 
lack of chemical constituent declarations in products, materials and goods. Humans and wildlife are simultaneously exposed to many EDCs, the measurement of the linkage between exposure to mixtures of EDCs and diseases is more physiologically relevant. Therefore there is a need to know where the exposures are coming from. Continuous monitoring for estrogenic activity in fruit and vegetables is critical, in view of the serious negative health effects these compounds pose in humans, wildlife and in the environment. Further research is needed to improve current knowledge, to identify and list potential endocrine disruptive activity by other chemicals, especially those replacing current ED before they are widely distributed. Finally, a thorough health risk assessment must be done to evaluate whether chemicals may cause adverse health effects, at what level, duration and frequency of exposure, and the probability that adverse health effects may occur.

Acknowledgements: The authors acknowledge the South African Table Grape Industry and the University of Pretoria, Institute of Food Nutrition and Well-Being and the Department of Science and Technology and National Research Foundation Centre of Excellence in Food Security for financing part of this study. We gratefully acknowledge editorial input from Ms Barbara English.

\section{References}

1. Anastassiades M, Lehotay SJ, Stajnbaher D, Schenck FJ. 2003. Fast and Easy Multiresidue Method Employing Acetonitile Extraction/Partitioning and "Dispersive Solid-Phase Extraction" for the Determination of Pesticide Residues in Produce, Journal AOAC International. 86:412-431.

2. Andersen HR, Vinggaard AM, Rasmussen TH, Gjermandsen IM, BonefeldJorgensen EC. 2002. Effects of currently used pesticides in assays for estrogenicity, androgenicity, and aromatase activity in vitro. Toxicology and Applied Pharmacology. Vol.179, No.1, (February 2002), pp. 1-12, ISSN 0041008X.

3. Ansara-Ross TM, Wepener V, Van Den Brink PJ, Ross MJ. 2012. Pesticides in South African fresh waters. African Journal of Aquatic Science. 37:1-16. 
4. Bempah CK, Buah-Kwofie A, Dzifa Denutsui D, Asomaning J, Tutu AO. 2011. Monitoring of pesticide residues in fruits and vegetables and related health risk assessment in Kumasi Metropolis, Ghana. Research Journal of Environmental and Earth Sciences. 3(6):761-771.

5. Bergman A, Heindel JJ, Jobling S, Kidd KA, Zoeller RT, Neira M, Becher G, Bjerregaard P, Bornman R, Brandt I, Kortenkamp A, Muir D, Drisse MB, Ochieng R, Skakkebaek NE, Byléhn AS, Iguchi T, Toppari J, Woodruff TJ. 2013. 1-29. The impact of endocrine disruption a consensus on the state of the science. Environmental Health Perspective 121 (4): A104-A106.

6. Bonefeld-Jorgensen EC, Grünfeld HT, Giermandsen IM. 2005. Effects of pesticides on estrogen receptor transactivation in vitro: a comparison of stable transfected MVLN and transient transfected MCF-7cells, Molecular and Cellular Endocrinology. 244 (1-2): 20-30.

7. Bornman MS, Van Vuren JHJ, Bouwman H, De Jager C, Genthe B, Barnhoorn IEJ. 2007. Endocrine disruptive activity and the potential health risk in an urban nature reserve. Water Research Commission Report No. 1505/1/07. Water Research Commission, Pretoria.

8. Cal Environmental Protection Agency. 2010. Development of Health Criteria for School Site Risk Assessment Pursuant to Health and Safety Code Section 901 (g): Child-Specific Reference Dose (chRD) for School Site Risk Assessment - Chlorpyrifos. Integrated Risk Assessment Branch, Office of Environmental Health Hazard Assessment, California Environmental Protection Agency. Available from http://oehha.ca.gov/public_info/public/kids/pdf/06171 0Chlorpyrifos.pdf.

9. Cederroth CR, Zimmermann C, Nef S. 2012. Soy, phytoestrogens and their impact on reproductive health. Molecular and Cellular Endocrinology. 355: 192-200.

10. Charles GD, Linscombe VA, Tornesi B, Mattson JL, Gollapudi BB. 2002. An in vitro screening paradigm for extracts of whole foods for detection of potential toxicants. Food and Chemical Toxicology. 40 (10): 1391-1402.

11. Chiu YH, Afeiche MC, Gaskins AJ, Williams PL, Petrozza JC, Tanrikut C, Hauser R, Chavarro JE. 2015. Fruit and vegetable intake and their pesticide residues in relation to semen quality among men from a fertility clinic. Oxford 
Journals Medicine \& Health Human Reproduction Volume 30, Issue 6 pp. 1342-1351.

12. Codex Alimentarius. 2000. Food Standards Programme. Pesticide Residue in Food. Methods of Analysis and Sampling. World Health Organization Vol. 2A Part 1.

13. Committee on Toxicity. 2002. Risk Assessment of Mixtures of Pesticides and Similar Substances, Committee on Toxicity of Chemicals in Food, Consumer Products and the Environment. Crown Copyright, Food Standard Agency.

14. Dabrowski JM, Shadung JM, Wepener V. 2014. Prioritizing agricultural pesticides used in South Africa based on their environmental mobility and potential human health effects. Environment International. 62:31-40.

15. De Jager C, Aneck-Hahn NH, Barnhoorn IEJ, Bornman MS, Pieters R, Van Wyk JH. 2011. The compilation of a toolbox of bio-assays for detection of estrogenic activity in water. Report No.WRC K5-1816. 2011.

16. Diamanti-Kandarakis E, Bourguignon JP, Giudice LC, Hauser R, Prins GS, Soto AM, Zoeller RT, Gore AC. 2009. Endocrine-disrupting chemicals: an Endocrine Society scientific statement. Endocrine Reviews.30:293-342.

17. Duran A, Tuzen M, Soylak M. 2007. Trace element levels in some dried fruit samples from Turkey. International Journal of Food Science and Nutrition. 59, 581-589.

18. Eaton DL, Daroff RB, Autrup H, Bridges J, Buffler P. 2008. Review of the toxicology of chlorpyrifos with an emphasis on human exposure and neurodevelopment. Critical Reviews in Toxicology 38 Supplement. 2:1-125.

19. Fang H, Tong W, Shi L M, Blair R, Perkins R, Branham W, Hass BS, Xie Q, Dial SL, Moland CL, Sheehan DM. 2001. Structure-activity relationships for a large diverse set of natural, synthetic, and environmental estrogens. Chemical Research in Toxicology. 14: 280-294.

20. Farag RS, Abdel Latif MS, Abd EL-Gawad AE, Dogheim SM. 2011. Monitoring of pesticide residues in some Egyptian herbs, fruits and vegetables. International Food Research Journal. 18: 659-655.

21. Ganna D, Sato A. 2005. The possible role of female sex hormones in milk from pregnant cows in the development of breast, ovarian and corpus uteri cancers. Medical Hypothesis. 65:1028-1037. 
22. Gray LE Jr, Wolf C, Lambright C, Mann P, Price M, Cooper RL, Ostby J. 1999. Administration of potentially antiandrogenic pesticides (procymidone, linuron, iprodione, chlozolinate, p,p'- DDE, and ketoconazole) and toxic substances (dibutyl- and diethylhexyl phthalate, PCB 169, and ethane dimethanesulphonate) during sexual differentiation produces diverse profiles of reproductive malformations in the malerat. Toxicology and Industrial Health. 15(1-2):94-118.

23. Grumfeld HT, Bonefeld-Jorgensen EC. 2004. Effects of in vitro estrogenic pesticides on human oestrogen receptor alpha and beta mRNA levels. Toxicological Letter. 15(3):467-80.

24. Iavicoli I, Fontana L, Bergamaschi A. 2009. The effects of metal as endocrine disruptors. Journal Toxicology and Environmental Health Part B Critical Review. 12: 206-223.

25. Järup L. 2003. Hazards heavy metal contamination. British Medical Bulletin.68: 167-182.

26. Joburg Market Business Plan. 2015/2016.Towards market for the future. Version 1.2. pp. 9.

27. Keith LH. 1998. Environmental endocrine disruptors. Pure and Applied Chemistry. 70:2319-2326.

28. Kilian E, Delport R, Bornman MS, De Jager C. 2007. Simultaneous exposure to low concentrations of dichlorodiphenyltrichloroethane, deltamethrin, nonylphenol and phytoestrogens has negative effects on the reproductive parameters in male Spraque-Dawley rats. Andrologia 39:128-135.

29. Kuo CC, Moon K, Thayer KA, Navas-Acien A. 2013. Environmental chemicals and type 2 diabetes: an updated systematic review of the epidemiologic evidence. Current Diabetes Report. 13:831-849.

30. Mendes JJ. 2002. The endocrine disrupters: a major challenge. Food Chemistry and Toxicology.Vol.40, No.6, (June 2002), pp. 781-788, ISSN 0278-6915.

31. Mehrpour O, Karrari P, Zamani N, Tsatsakis AM, Abdollahi M. 2014. Occupational exposure to pesticides and consequences on male semen and fertility: a review. Toxicology Letter.230:146-156. 
32. Metzler M, Kullin SE, Pfeiffer E, Jacobs E. 1998. Genotoxicity of estrogens. Z Lebensm Unters Forsch A. 206:367-373.

33. Mnif W, Hassine AI, Bouaziz A, Bartegi A, Thomas O, Roig B. 2011. Effect of endocrine disruptor pesticides: a review. International Journal of Environmental Research and Public Health.8:2265-2303.

34. Moon YJ, Wang X, Morris ME. 2006. Dietary flavonoids: Effects on xenobiotic and carcinogen metabolism. Toxicology in Vitro. 20:187 - 210.

35. National Institute of Environmental Health Sciences. 2006. Endocrine disruptors. Available from http://www.niehs.nih.gov/health/topics/agents/endocrine/doc/Endocrine.pdf.

36. Ostby J, Kelce WR, Lambright C, Wolf CJ, Mann P, Gray Jr LE. 1999. The fungicide procymidone alters sexual differentiation in the male rat by acting as an androgen-receptor antagonist in vivo and in vitro. Toxicology and Industrial Health 1580-93.

37. Pesticide Action Network. 2010. Pesticide Action Network (PAN) Pesticide database, 20.03.2011, Available fromhttp://www.pesticideinfo.org.

38. Persistent Organic Pollutants Review Committee. 2010. Recommendation of the Persistent Organic Pollutants Review Committee (POPRC) on Endosulfan. Available from http://chm.pops.int.

39. Routledge EJ, Sumpter JP. 1996. Estrogenic activity of surfactants and some of their degradation products assessed using a recombinant yeast screen. Environmental Toxicology and Chemistry. 15(3):241-248.

40. Santti R, Mäkelä S, Strauss L, Korkman J, Kostian ML. 1998. Phytoestrogens: potential endocrine disruptors in males. Toxicology and Industrial Health. 14: 223-237.

41. Sarma Q, Kalita J. 2012. Estrogenic nature and effects of endosulfan in white albino mice. International Journal of Scientific and Research Publication. Vol 2, Issue 1: 1-6.

42. Svechnikov K, Izzo, G, Landreh, L, Weisser J, Söder O. 2010. Endocrine Disruptors and Leydig Cell Function. Journal of Biomedicine and Biotechnology. 1-11. 
43. Shaw I, McCully S. 2002. A review of the potential impact of dietary endocrine disrupters on the consumer. International Journal of Food Science and Technology. 37:471-476.

44. Schiliro T, Gorrasi I, Longo A, Coluccia S, Gilli G. 2011. Endocrine disrupting in fruits and vegetables evaluated with the E-screen assay in relation to pesticide residues. Journal of Steriod Biochemistry and Molecular. 127:139-146.

45. Sirtori CR, Arnoldi A, Johnson SK. 2005. Phytoestrogens: End of a tale? Annals of Medicine.37:423-438.

46. Sonnenschein C, Soto AM. 1998. An updated review of environmental estrogen and androgen mimics and antagonists. Journal of Steroid Biochemistry and Molecular Biology. 65(1-6):143-150.

47. Soto AM, Chung KI, Sonneschein C. 1994. The pesticide endosulfan, toxaphene and dieldrin have estrogenic effects on human estrogen-sensitive cells. Environmental Health Perspectives. 102(4):380-383.

48. South African local maximum residue limits (As published by the Department of Health). Available from the Department of Agriculture, Forestry and Fisheries website http://www.daff.go.za.

49. Thayer KA, Heindel JJ, Bucher JR, Gallo MA. 2012. Role of environmental chemicals in diabetes and obesity: a National Toxicology Program workshop review. Environmental Health Perspectives. 120: 779-789.

50. Tomigahara Y, Suzuki N, Tarui H, Saito K, Kaneko, H. 2014. Anti-androgenic activity of procymidone and its metabolites. Journal of Pesticide Science. 39 (4):181-186.

51. United States Environmental Protection Agency. 2002. Re-registration Eligibility Decision for Endosulfan. EPA738-R-02-013. Pollution, Pesticides and Toxic Substances (7508C), United States Environmental Protection Agency. Available from http://www.epa.gov/oppsrrd1/REDs/endosulfan red.pdf.

52. United States Environmental Protection Agency. 2011. Memorandum. Chlorpyrifos: Preliminary Human Health Risk Assessment for Registration Review. DP No. D388070. June 30th. Office of Pesticide Programs, United States Environmental Protection Agency, Washington, D.C. 
53. Verma A, Ali D, Farooq M, Pant AB, Ray RS, Hans RK. 2011. Expression and inducibility of endosulfan metabolizing gene in Rhodococcus strain isolated from earthworm hut microflora for its application in bioremediation. Bioresource Technology. 102(93):2979-2984.

54. Viswanath G, Chatterjee S, Dabral S, Nanguneri SR, Divya G, Roy P. 2010. Anti-androgenic endocrine disrupting activities of chlorpyrifos and piperophos. Journal of Steroid Biochemistry and Molecular Biology. 120:2229.

55. Watson WH, Jager JD. 2007. Arsenic: extension of its endocrine disruption potential to interference with estrogen receptor-mediated signalling. Toxicological Science. 98: 1-4.

56. World Health Organization.2002. Global assessment of the state-of-thescience of endocrine disruptors, eds. Damastra T, Barlow S, Bergman A, Kavlock R, Der Kraak V. Geneva: WHO.

57. World Health Organization. 2003. State of the Art Report: Health risks in aquifer recharge using reclaimed water. SDE/WSH/03.08. World Health Organization, Geneva.

58. Wilson VS, Bobseine K, Gray LE Jr. 2004. Development and characterization of a cell line that stably expresses an estrogen-responsive luciferase reporter for the detection of estrogen receptor agonist and antagonists. Toxicological Science. 81:69-77.

59. Ying GG, Kookana, R, Waite TD. 2004. Endocrine disrupting chemicals and pharmaceuticals and personal products (PPCPs) in reclaimed water in Australia. Australia Water Conservation and Research Programme Report.

60. Zeliger HI. 2013. Lipophilic chemical exposure as a cause of cardiovascular disease. Interdisciplinary Toxicology. 6: 55-62.

61. Ziarati P, Arbabi S, Arbabi Bidgoli S, Qomi M. 2013. Determination of lead and Cadmium Contents in (oryzasativa) rice samples of agricultural areas in Gillan- Iran. International Journal of Farming and Allied Sciences. 2(11): 268271. 